\title{
Exploring and Practice of Cooperative Learning in Teaching Microbiology
}

\author{
Ruimin $\mathrm{Fu}$ \\ Department of Life Science, \\ Henan institute of education, \\ Zhengzhou, Henan province, P.R.C \\ angelaminmin@163.com
}

\begin{abstract}
In order to promote mutual assistance and complete learning tasks of students in a heterogeneous group, the cooperative learning was used in this study. In this paper, the teaching model of cooperative learning was explored and practiced by combining it with teaching microbiology. As was shown in the result, the use of cooperative learning in teaching microbiology can not only stimulate the interest of students to learn but also encourage their participation and cooperation, and improve their practice and innovation skills. To sum up, by using cooperative learning method, learning efficiency and creativity of students has been improved. Moreover, Learning autonomy and enthusiasm are significantly improved in this teaching method.
\end{abstract}

Keywords-cooperative learning; heterogeneous group; microbiology teaching

\section{INTRODUCTION}

Microbiology is a fundamental subject in biology and a compulsory course for biotechnology and applied professional students[1]. This subject is highly experimental; thus, substantial knowledge in microbiology is obtained through observations and experiments[2-4]. Understanding comprehensively and intuitively by only listening to teachers is difficult for students. Thus, teachers should not only provide the relevance of the role of education to learning but also organize classroom teaching[5]. Preparing students to seek answers by themselves, and analyze and solve problems with initiative is possible if teachers will make students participate in the learning process[6-8]. Participation in the learning process can enhance the sense of participation, cooperation, and innovation of students through their own observations, experiments, and conclusions[9-12]. However, the following are the several aspects in the current teaching of microbiology in college that should be improved:

\section{A. Students who learn slowly and lac creativity tend not to participate in the classroom}

The traditional teaching model is teacher-centered[13-15] and does not promote student participation. In this kind of teaching model, students become passive learners who mechanically follow their teachers, thereby making them slow learners. Passive acquisition of knowledge negatively affects the initiative of students to process information and inhibit critical thinking[16-18].

\section{B. Highly dependent students lose their learning interest and initiative}

The teaching method adopted in our university is Influenced by the traditional synchronous teaching model, where teaching and learning are simultaneous[19-20]. That is, learning is only done in the classroom in a hasty and condensed manner. Consequently, students find remembering their lessons difficult through this method[21-24]. Students and teachers almost do not interact in this classroom setting. This teaching method ignores the subjective conditions of the students themselves, namely, cognitive ability, personality characteristics, and differences in knowledge and experience. As a result, students become strongly dependent that they cannot think critically by themselves and have difficulties in learning. Over time, students lose their enthusiasm and initiative in learning.

In view of the above problems, the author has improved the teaching method in teaching microbiology and immunology courses. In accordance to the individual differences of students, the author adopts cooperative learning and has achieved excellent results.

\section{Cooperative Learning And Specific Procedures}

Cooperative learning combines classroom teaching and group activities in the form of teaching organization. Moreover, the method uses a heterogeneous group. Members of the group vary in age, sex, educational background, etc. This diversity ensures the complementarity among the members of the group and their cooperation in group activities. Simultaneously, each group should also be homogeneous. The diversity within the group is the foundation for homogeneity, ensuring fair competition among the students.

For example, in cooperative learning, a class is divided into 10 groups with approximately 4 students in each group. Each member of the group has a specific role, such as group leader, recorder, data collector, and spokesperson. The duty of the team leader is to organize cooperative learning activities; the data collector is responsible acquiring Information; the recorder documents that information; and the spokesperson acts in behalf of the group and report their output. 
The application of cooperative learning in teaching microbiology is divided into the following five fundamental steps:

(1) Create a thematic situation;

(2) Ensure cooperation by dividing the class into groups;

(3) Students initiate learning through group cooperation;

(4) Evaluate the situation by communicating within the group, creating multiple ideas; and

(5) Impart knowledge to other group members through induction.

\section{USING COOPERATIVE LEARNING APPROACH IN TEACHING MICROBIOLOGY}

\section{A. Create a thematic situation}

Teachers first need to present a relevant question to the subject matter. For example, "People eat food. They must eat nutritious food to be healthy and maintain the normal operation of various tissues and organs of their body. Similarly, bacteria have to eat as well. If you were a chef to bacteria, how would you plan a meal for the bacteria?" Through this thematic situation, the students will have something to discuss, promoting teacher-student interaction.

\section{B. Ensuring cooperation by dividing the class into groups}

People eat three meals a day to get enough nutrients. Correspondingly, the growth and reproduction of bacteria are necessary for some nutritional elements. For instance, bacteria are the source of carbon in bread and rice. The bacteria are also a source of nitrogen. Trace elements of salt calcium supplement can also be produced by bacteria. Humans decompose carbohydrates through the oxidation of energy, whereas bacteria decompose carbon and nitrogen sources, or acquire light energy through oxidation. Thus, both humans and bacteria need adequate intake of vitamins and water to ensure optimum growth.

After establishing the lesson above, the teachers may ask, "What are the different nutrients needed for the carbon source of energy in bacterial growth? Also, give examples of the several types of nutrition produced in bacterial growth." To elicit response from students, a textbook itself can discuss, explain, and differentiate the nutritional types of bacteria, which can lead the students to relate their life experiences and explain how various types of bacteria affect the productive life of humans.

\section{Students initiate learning through group cooperation}

Students need to develop cooperative learning in group to determine the factors affecting bacterial growth. The growth conditions of bacteria are affected by temperature, $\mathrm{pH}$, osmotic pressure, oxygen concentration, and water activity. Students are allowed to work as a unit to explore and discuss the growth factors through an experiment. Students show great interest in a group learning process, expressing their views, taking turns in discussion, offering advice, and having a collaborative relevant knowledge discussion. In turn, teachers learn to understand the situation through the process, and are able to guide and coach the students. After a session, students can finally understand the growth conditions of bacteria and its nutrient. This part fully reflects the significant roles of students and teachers in cooperative learning.

\section{Evaluate the situation by communicating within the group, creating multiple ideas}

In this part, students display and evaluate the task results in groups. Study materials, pictures, or PowerPoint presentations are used to explain the views of the group before class. Students can add entertainment in their reporting. For example, the nutrients absorbed by bacteria, such as glucose, fructose, and mannose, are represented by the "cap behavior" of the group shift. However, the "cap" actually refers to the acid supply of the phosphorene acetone of the phosphate group. The metaphor vividly indicates the characteristics of the group shift, which is entertaining and impressive. Group communication, active classroom atmosphere through inter-group discussion, self-assessment, and assessment of the cognitive understanding of the groups are some of the characteristics of the cooperative learning method.

\section{E. Induction and knowledge transfer}

In this paper, the author analyzed the problems of group learning. Thus, a new problem scenario is created: "Do you like to eat kimchi and candied fruits?" Regarding the special taste of raisins, how did the Turpan residents acquire the exquisite, sweet and sour taste of their grapes? This question can effectively stimulate students to formulate theories, thereby understanding the purpose of migration. This section laid a foundation suitable for consolidating the content.

\section{The EFFECt OF COOPERATIVE LEARNING}

\section{A. Improving learning efficiency and creativity of students through cooperative learning}

Compared with traditional teaching, teachers both guide and discuss. Students only have a supporting role or even background role in traditional teaching method. However, in cooperative learning, teachers act as the director, while students are the actors. Through cooperative learning, the subjective position of the students is reflected in the teaching situation. Cooperative learning starts from the students. Then, through the guidance of their teachers, student cooperates and interacts with one another and their teachers. Classroom time is all about the students in cooperative learning. Thus, students participate actively.

Teachers provide links for students to find a deeper meaning of the lessons they learn. Over time, students improve their creativity and learning efficiency.

\section{B. Learning independently by students through cooperative learning}

In traditional teaching, teachers teach, while students only copy, which results to passive learning. Conversely, in cooperative learning, students study independently, boldly exploring the conditions. Moreover, the students continue 
finding and solving problems in the study process, according to the prompt of their teachers. In cooperative learning, the source of learning comes from the students. Learning autonomy and enthusiasm are significantly improved in this teaching method.

\section{CONCLUSION}

After spending a semester of exploring and practicing the teaching method of cooperative learning, I deeply appreciate that the method can fully mobilize students to participate in learning, thus promoting learning itself, which can effectively enhance the self-learning ability and thinking skills of students. Cooperative learning can greatly improve the efficiency of classroom teaching. Simultaneously, students learn from one another other, which bring mutual help.

Moreover, the teaching method enhances the interpersonal communication skill, both in presenting one's self and in sharing the dedication to the group. Students can master the knowledge and skills, and develop the ability to experience a different point of view after the interacting. The emotional exchanges among students can be redirected into learning. The mutual cooperation and the exercise of fair competition among the groups heighten the cooperation and sense of competition of students. The learning experience of students also improves their psychological quality, which lays a solid foundation for lifelong learning. Teachers and students are all enthusiastic throughout the entire course of microbiology.

However, cooperative learning also has disadvantages[2526]. Students with poor self-management ability and lack of cooperative learning awareness and ability lead to low and imbalanced participation from students. These problems will be addressed in the future through practice, and continuous exploration and improvement.

\section{ACKNOWLEDGMENT}

This work was financially supported by Agricultural Science and Technology Achievements Transformation Fund Project (2012GB2G000451) and Youth Scientific Research Projects in Henan Institute of Education (20100103)

\section{REFERENCES}

[1] Michaelsen L, Davidson N, Major C H. Team-based learning practices and principles in comparison with cooperative learning and problembased learning $[\mathrm{J}]$. Journal on Excellence in College Teaching, 2014, 25(3-4): 57-84.

[2] Sampaio - Maia B, Maia J S, Leitão S, et al. Wiki as a tool for Microbiology teaching, learning and assessment[J]. European Journal of Dental Education, 2014, 18(2): 91-97.

[3] Khan F M A, Masood M. The Effectiveness of an Interactive Multimedia Courseware with Cooperative Mastery Approach in Enhancing Higher Order Thinking Skills in Learning Cellular Respiration[J]. Procedia-Social and Behavioral Sciences, 2015, 176: 977-984.

[4] Luginbuhl S C, Hamilton P T. Cooperative learning through team-based projects in the biotechnology industry[J]. Journal of Microbiology \& Biology Education: JMBE, 2013, 14(2): 221.

[5] Wang $\mathrm{J}, \mathrm{Hu} \mathrm{X}, \mathrm{Xi} \mathrm{J}$. Cooperative learning with role play in Chinese pharmacology education[J]. Indian journal of pharmacology, 2012, 44(2): 253.
[6] Hasruddin H, Mahmud M. The Effectiveness of Learning Tools of Applied Microbiology to Students Learning Outcomes and Softskill[C]/Prosiding Seminar Biologi. 2016, 12(1): 591-594.

[7] Moghadam Z S, Moghadam F S, Zarein-Dolab S, et al. The Effectiveness of Cooperative Learning in Teaching English for Specific Purposes to the Students of Nursing Regarding Pronunciation[J]. Educational Research in Medical Sciences Journal, 2016, 5(1): 9-15.

[8] Shukla N J, Hassani H, Casleton R. A Comparison of Delivery Methods for Distance Learning Mathematics Courses[J]. 2014.1(1)1-10

[9] Shukla N J, Hassani H, Casleton R. A Comparison of Delivery Methods for Distance Learning Mathematics Courses[J]. 2014.

[10] Chen J, Zhou J, Sun L, et al. A new approach for laboratory exercise of pathophysiology in China based on student-centered learning[J]. Advances in physiology education, 2015, 39(2): 116-119.

[11] López-Íñiguez G, Pozo J I. Like teacher, like student? Conceptions of children from traditional and constructive teachers regarding the teaching and learning of string instruments[J]. Cognition and Instruction, 2014, 32(3): 219-252.

[12] Boucaud D W, Nabel M, Eggers C H. Oxford-style debates in a microbiology course for majors: A method for delivering content and engaging critical thinking skills[J]. Journal of Microbiology \& Biology Education: JMBE, 2013, 14(1): 2.

[13] Wang J T H. Using undergraduate research to develop transferable skills for the modern workforce[J]. Microbiology Australia, 2016, 37(2): 8487.

[14] Zollner B, Sucha M, Berg C, et al. Pharmacases. de-A student-centered e-learning project of clinical pharmacology[J]. Medical teacher, 2013, 35(3): 251-253.

[15] Lee S D, Kim G Y. Effects of Learning Community Activity on Communication Skills and Self-Directed Learning Ability[J]. Journal of the Korea Academia-Industrial cooperation Society, 2015, 16(12): 82498261.

[16] Jarjoura C, Abou Tayeh P, Zgheib N K. Using Team-Based Learning to Teach Grade 7 Biology: Student satisfaction and improved performance[J]. Journal of Biological Education, 2015, 49(4): 401-419.

[17] Jiugen Y, Ruonan X, Wenting Z. Essence of flipped classroom teaching model and influence on traditional teaching[C]//Electronics, Computer and Applications, 2014 IEEE Workshop on. IEEE, 2014: 362-365.

[18] Zhao N, Valcke M, Desoete A, et al. Does teacher-centered teaching contribute to students' performance in primary school? A video analysis in Mainland China[J]. International Journal of Research Studies in Education, 2014, 3(3):1-10.

[19] Thompson J, Windschitl M, Braaten M. Developing a theory of ambitious early-career teacher practice[J]. American Educational Research Journal, 2013, 50(3): 574-615.

[20] Clarke A, Triggs V, Nielsen W. Cooperating teacher participation in teacher education a review of the literature[J]. Review of Educational Research, 2014, 84(2): 163-202.

[21] Lee W A S S, Rengasamy S, Hooi L B, et al. The Effectiveness of Teaching Games for the Improvement of the Hockey Tactical Skills and the State of Self-Confidence among 16 Years Old Students[J]. World Academy of Science, Engineering and Technology, International Journal of Social, Behavioral, Educational, Economic, Business and Industrial Engineering, 2015, 9(7): 2296-2302.

[22] Xia S, Cao X, Yin G, et al. Application of PBL Model in the Teaching of Foreign Graduate Student[M]//Frontier and Future Development of Information Technology in Medicine and Education. Springer Netherlands, 2014: 1797-1802.

[23] Kumaravadivelu B. Rethinking global perspectives and local initiatives in language teaching $[\mathrm{J}]$. Teachers and Teaching: Global Perspectives, 2013: 317-323.

[24] Tseng C H, Tuan H L, Chin C C. How to help teachers develop inquiry teaching: Perspectives from experienced science teachers[J]. Research in Science Education, 2013, 43(2): 809-825.

[25] Leonardi P M, Huysman M, Steinfield C. Enterprise social media: Definition, history, and prospects for the study of social technologies in organizations[J]. Journal of Computer - Mediated Communication, 2013, 19(1): 1-19. 